\title{
Cyclen-Containing Inhibitors of Carboxypeptidase A Synthesized in Search of Target-Selective Artificial Proteases ${ }^{\dagger}$
}

\author{
Jung Bae Song, Sang Soo Hah, and Junghun Suh * \\ Deparment of Chemistr, Seoul National Cniversity, Seoul 151-747, Korea \\ Received March 22, 2004
}

Key Words : Carboxypeptidase A. Peptide-cleaving catalyst. Inhibitor

Previously, we reported the first substrate-selective artificial protease by using myoglobin as the substrate. ${ }^{1.3}$ Target-selective peptide-cleaving catalysts can be used as drugs if the target is a protein or an oligopeptide related to a disease. For example, a peptide-cleaving cataly st specifically recognizing HIV protease and rapidly cleaving it into two pieces can be used as a new drug for AIDS. Since only a catalytic amount of the drug is needed. the drug dosage and the side effects can be reduced by using the peptide-cleaving catalysts.

The myoglobin-cleaving catalysts reported previously were designed by attaching a cataly tic group to a binding site that recognizes the surface of nyoglobin. ${ }^{1 . \hat{3}}$ The $\mathrm{Cu}(\mathrm{II})$ or Co(III) complex of cyclen (Cyc) was used as the catalytic group in view of their cataly tic activity in peptide hy drolysis. Thus, connection of a cataly tic group to a binding site can be considered as a general method for creation of targetselective peptide-cleaving catalysts. The binding site may recognize either a certain portion on the surface of the target protein as in the case of the myoglobil-cleaving catalyst mentioned above or the active site of the target protein. In view of a vast amount of ligand molecules reported to have high affinity toward many disease-related proteins. the known ligand molecules may be utilized as the binding site of the peptide-cleaving catalysts. In this regard. we undertook synthesis of peptide-cleaving catalysts selective for carbosypeptidase A (CPA) by using CPA inhibitors as the binding site of the catalysts. The idea of designing a CPA-selective peptide-cleaving catalyst based on a known CPA inhibitor is illustrated in Scheme I

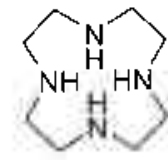

Cyc

Among many inhibitors of CPA reported in the literature. phosphonate analogues of CPA substrates such as $A_{]}-A_{\text {: }}$ are the most potent. ${ }^{4,5}$ The X-ray crystallographic study performed on the phosphonate inhibitors disclosed that the L- $\beta$ phenyllactic acid (PLA) moiety containing the hydroxyalhylphosphinyl group occupied the active site. ${ }^{6}$ Thus, the

This paper is dedicated to Professor Yong Hae Kim for his distinguished achievements in chemistry.

"Corresponding Author. e-mail: jhsulh acsill.ac.kr

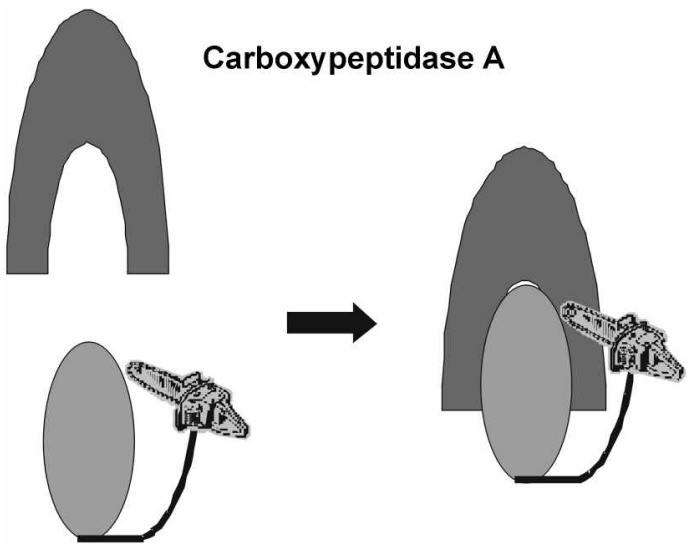

Scheme 1. Designing CPA-selective peptide-cleaving catalysts based on a known CPA inhibitor.

hydroxyalkylphosphinyl ester (Ai) of PLA can be exploited as binding sites of the CPA-cleaving catalysts. In this study, we synthesized various derivatives of Cyc containing $A_{c}$. We speculated that those Cyc derivatives might be converted to effective CPA-cleaving catalysts upon binding of $\mathrm{Cu}(\mathrm{II})$ or Co(III) in view of their ability to recognize the active site of CPA. Structures of the Cyc-containing inhibitors synthesized

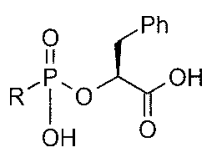

$\mathrm{A}_{0}$<smiles>O=C(NC(Cc1ccccc1)C(=O)NCP(=O)(O)OC(Cc1ccccc1)C(=O)O)c1ccccc1</smiles><smiles>CC(NC(=O)NC(Cc1ccccc1)P(=O)(O)OC(Cc1ccccc1)C(=O)O)C(=O)OCc1ccccc1</smiles>

$\mathrm{A}_{4}$<smiles>CC(NC(=O)OCc1ccccc1)C(=O)NCP(=O)(O)OC(Cc1ccccc1)C(=O)O</smiles><smiles>CC(C)[C@H](NC(=O)C(Cc1ccccc1)NC(=O)c1ccccc1)P(=O)(O)OC(Cc1ccccc1)C(=O)O</smiles>

$A_{1}$<smiles>CC(NC(=O)NC(C)(O)P(=O)(O)OC(Cc1ccccc1)C(=O)O)C(=O)NC(C)(C)C</smiles>

$\mathrm{A}_{3}$<smiles>CC(NC(=O)C(C)NC(=O)P(=O)(O)OC(Cc1ccccc1)C(=O)O)C(=O)Nc1ccccc1</smiles>

$A_{5}$ 


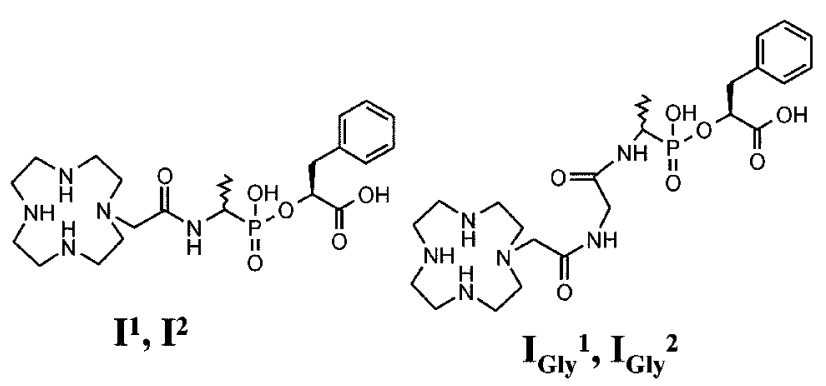

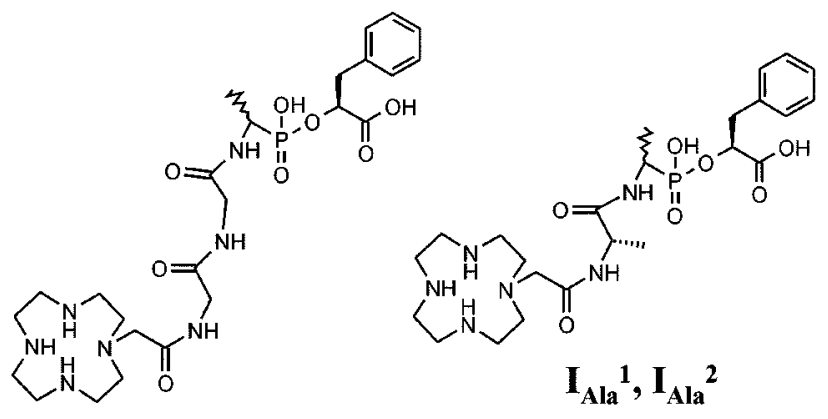

$$
I_{\text {GlyGly }}{ }^{1}, I_{\text {GlyGly }}^{2}
$$

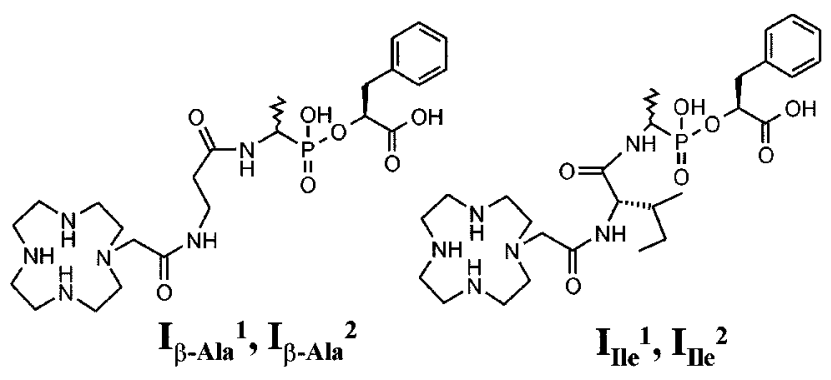

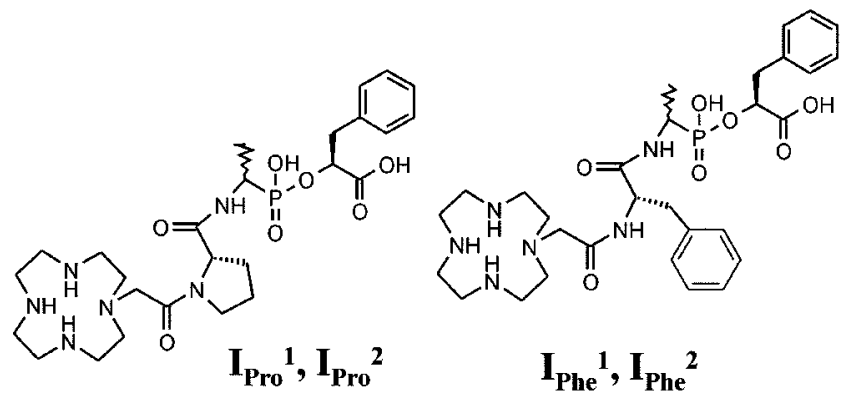

Figure 1. Cyc-containing inhibitors of CPA synthesized in the present stud:

in this study are illustrated in Figure 1.

The Cyc-containing inhibitors listed in Figure 1 were prepared according to the synthetic route summarized in Scheme 2. Since the enantiomeric mixture of 1 was used in the synthesis. diastereomeric mixtures were obtained for the Cyc-containing inhibitors. The diastereomeric mixture was separated by HPLC as described in the Experimental Section and the isomer with the shorter elution time was denoted by superscript $l$ in the nomenclature and the one with the longer elution time by superscript 2 . As will be shown later. the isomers with longer elution times were more potent inhibitors for CPA compared with the respective isomers with shorter elution times. Since it is well established that L- configuration at the chiral carbon has much greater affinity toward CPA., L-configuration was assigned to the stereoisomers with longer elution times. Concentrations of the Cyc-containing inhibitors separated by HPLC were determined by spectral titration using $\mathrm{CuCl}_{2}$ by following the formation of $\mathrm{Cu}(\mathrm{II})$ complex of $\mathrm{Cyc}$.

Inhibition constants $\left(K_{i}\right)$ for the $\mathrm{Cyc}$-containing inhibitors in the action of CPA were measured without insertion of $\mathrm{Cu}$ (II) or $\mathrm{Co}$ (III) ion into the $\mathrm{Cyc}$ moieties. The kinetic data were collected by using $p$-chlorocinnamoyl PLA $(\mathrm{ClCPL})^{7.8}$ as the substrate by following the disappearance of the substrate (S) spectrophotometrically at $315 \mathrm{~nm}$. As reported previously. ${ }^{8}$ the CPA-catalyzed hydrolysis of esters like CICPL is complicated by product inhibition by PLA and the plots of ln [S] against time deviate from the pseudo-firstorder kinetic beliavior. Even for the enzymatic reactions competitively inhibited by the product. the initial rate is expressed as eq. (1) under the conditions of $S_{0} \gg E_{0}$. From the dependence of the initial rate constant, $k_{\text {in }}\left(=v_{\mathrm{d}} / \mathrm{S}_{\mathrm{j}}\right)$, on the initially added substrate concentration $\left(S_{\mathrm{j}}\right) . k_{\mathrm{cat}}$ and $K_{\mathrm{m}}$ can be estimated.

$$
v_{\mathrm{s}}=(-\mathrm{d}[S] / \mathrm{dt})_{t=0}=k_{\mathrm{un}} S_{\mathrm{o}}=k_{\text {cat }} E_{\mathrm{c}} S_{\mathrm{c}} /\left(K_{\mathrm{m}}+S_{\mathrm{s}}\right)
$$

We estimated $k_{\text {in }}$ by fitting the absorbance change observed during the CPA-catalyzed hydrolysis of ClCPL according to eq. (2). Here. $A_{\mathrm{i}}$ and $A_{\mathrm{F}}$ represents the absorbance reading for the reaction mixture measured at time $t_{j}$ and the absorbance reading of the product solution measured after completion of the reaction. respectively. The term $\ln \left(A_{\mathrm{i}}-A_{\mathrm{F}}\right)$ is related to $\ln [S]_{\mathrm{i}}$ and the term $a t_{i}{ }^{2}$ reflects the degree of deviation from the pseudo-first-order kinetic beltavior. By least-square analysis using a computer program (Sigma Plot). the best parameter values were estimated for $a . b$, and $c$. Since $b$ is the slope of the tangent line of $\ln \left(A_{\mathrm{j}}-A_{\mathrm{F}}\right)$ drawn at the initial reaction time. $\mathrm{b}$ is taken as $k_{\text {in. }}$. The $k_{\text {in }}$ values measured at various $S$ values were fitted to eq. (1) by the Sigma Plot program: $k_{\mathrm{cat}}$ of $109 \pm 5 \mathrm{~s}^{-1}$ and $K_{\mathrm{m}}=82.0 \pm 10.2$ $\mu \mathrm{M}\left(k_{\mathrm{cat}} / K_{\mathrm{m}}=1.33 \times 10^{6} \mathrm{~s}^{-1} \mathrm{M}^{-1}\right)$ were obtained which may be compared with the literature values of $144 \mathrm{~s}^{-1}$ and 136 $\mu \mathrm{M}\left(k_{\mathrm{c} \text { st }} / K_{\mathrm{m}}=1.06 \times 10^{6} \mathrm{~s}^{-1} \mathrm{M}^{-1}\right)$. respectively: measured with a different isozyme of CPA.

$$
-\ln \left(A_{1}-A_{\mathrm{p}}\right)=\mathrm{a} t_{1}{ }^{2}+\mathrm{b} t_{1}+\mathrm{c}
$$

In the presence of a competitive inhibitor with initial concentration of $I_{\mathrm{c}}$. the initial rate is expressed as eq. (3) under the conditions of $S_{0} \gg E_{0}$ and $I_{0} \gg E_{0}$. By fixing $S_{\circ}$ and $E_{\mathrm{c}}$ at constant values. $k_{\text {in }}$ values were measured at various $I_{\mathrm{o}}$ values. By analyzing the dependence of $k_{\mathrm{in}}$ on $I_{\mathrm{s}} . K_{\mathrm{j}}$ values were estimated. For correct estimation of $K_{\mathrm{j}}, I_{ }$should be neither too large nor too small compared with $K_{\mathrm{i}}$.

$$
k_{\mathrm{m}}=k_{\mathrm{cat}} E_{\mathrm{o}} /\left(K_{\mathrm{m} 1}+I_{\mathrm{o}} K_{\mathrm{m}} / K_{1}-S_{\mathrm{o}}\right)
$$

Equilibrium between CPA and the inhibitors can be reached within less than a few minutes when $I_{0}$ is sufficiently high. In the case of very potent inhibitors. the initial equilibrium mixtures obtained by mixing CPA and the inhibitor was further diluted in order to lower $I_{0}$ to a value 

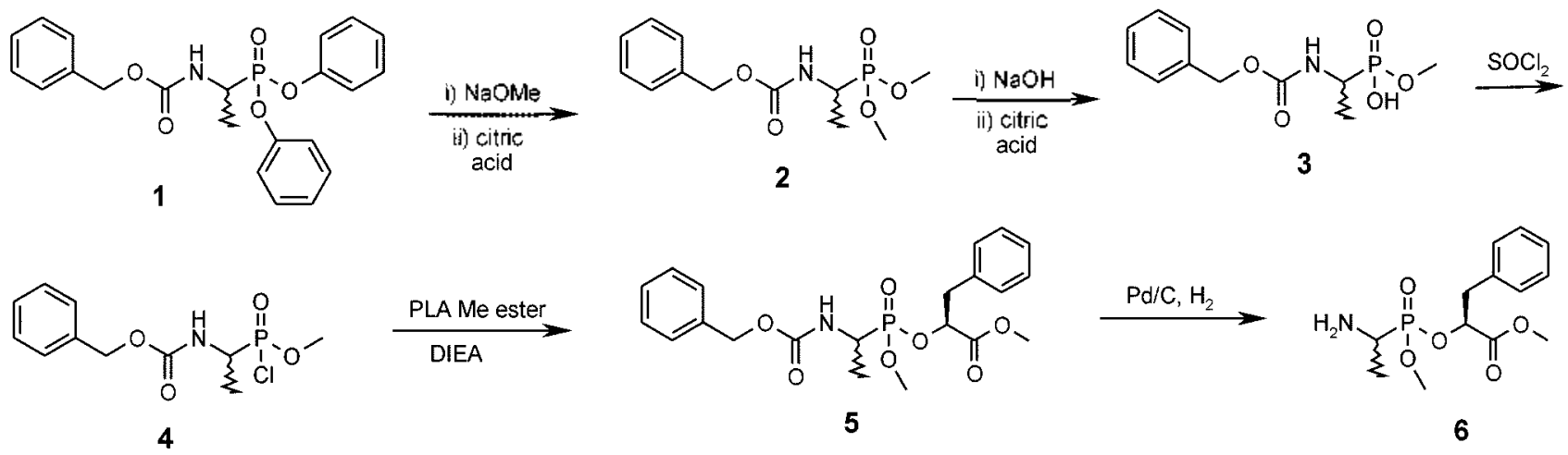<smiles>CCOC(=O)[C@H](N)Cc1ccccc1</smiles>

7

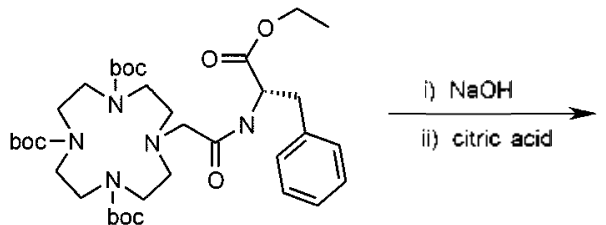

8<smiles>O=C(CCN(CCN1CCN(C(=O)O)CC1)C(=O)O)N[C@@H](Cc1ccccc1)C(=O)O</smiles>

9

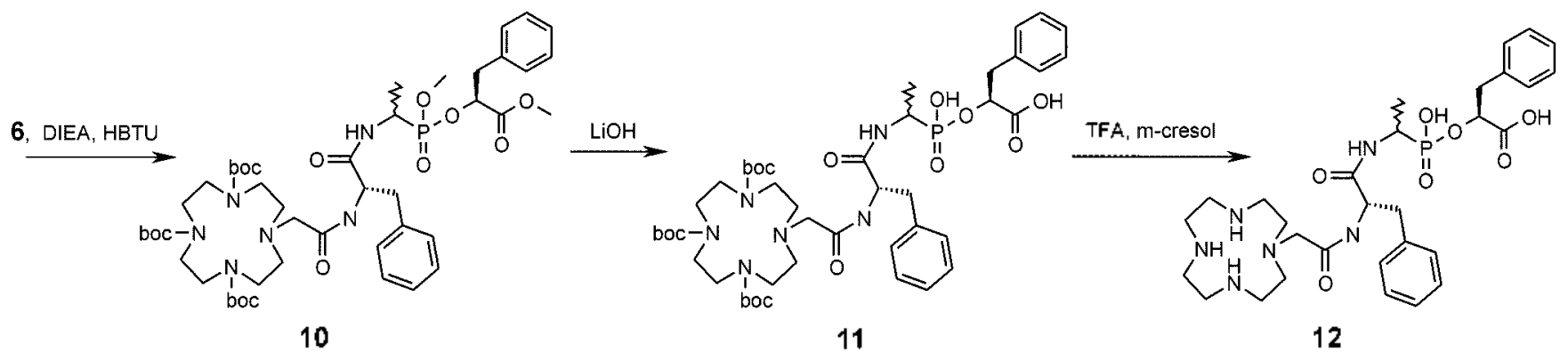

Scheme 2. A typical synthetic route for the Cyc-containing inhibitors of CPA.

comparable to $K_{\mathrm{i}}$ with maintaining the condition of $I_{0} \gg E_{0}$. To reach the new equilibrium, $E I$ complex should dissociate to $E$ and $I$ which can take long when $K_{\mathrm{i}}$ is very low. ${ }^{45}$ For the potent inhibitors examined in this study. the new equilibrium was attained within 1-2 hours as checked by assay with ClCPL. Dissociation of EI during readjustment of the equilibrium states demonstrates the reversible nature of the $E I$ formation in the case of the Cyc-containing inhibitors. This excludes the possibility of $\mathrm{Zn}$ (II) abstraction from CPA to the $\mathrm{Cy}$ c moiety in the $E I$ complex. In the $\mathrm{X}$-ray crystallographic structures of CPA complexes formed with the $A_{1} . A_{3}$. and related inhibitors. the two oxygen atoms attached to the phosphorus atom of the inhibitor is bound by the $\mathrm{Zn}(\mathrm{II})$ ion of CPA. ${ }^{6}$ If a similar binding mode is operative for the $\mathrm{Crc}$-containing inhibitors. it is not possible to transfer the $\mathrm{Zn}$ (II) bound by the phosphonyl oxygen to the Cyc moiety in the $E I$ complex.

The $K_{\mathrm{i}}$ values for the Cyc-containing inhibitors of CPA investigated in this study are summarized in Table 1. together with those for $\mathrm{A}_{1}-\mathrm{A}_{6}$ reported in the literature. The most potent inhibitor synthesized in this study is $\mathrm{I}_{\mathrm{Pro}}{ }^{2}$. Inhibitors $A_{2} . A_{\hat{j}}$. and $A_{s}$ as well as the Cyc-containing inhibitors contain phosphonic acid analogue of $\mathrm{L}-\mathrm{Ala}$. $\mathrm{I}_{\mathrm{Ala}}{ }^{2}$ is an analogue of $A_{j}$ and $A_{\xi}$ which differ only in the acyll group attached to the $N$-termini. Similarly, $\mathrm{I}_{\mathrm{Phe}}{ }^{2}$ is an analogue of $\mathrm{A}_{2}$. Although $\mathrm{I}_{\mathrm{Phe}}{ }^{2}$ is a considerably weaker inhibitor of $\mathrm{CPA}$ compared with $A_{\Sigma_{2}} I_{A_{1}}{ }^{2}$ is as potent as $A_{3}$ or $A_{5}$. This suggests that the effect of the Cyc-acetyl group on CPA inhibition is similar to those of $\mathrm{Cbz}$ or dansyl groups. despite the unique structure of $\mathrm{Cyc}$. $\mathrm{Cyc}$ is present as a protonated form at neutral $\mathrm{pHs}$ and contains several sites capable of hydrogen-bond formation with CPA. These structural features apparently did not affect the binding of the Cyccontaining inhibitors by CPA.

To test whether the $\mathrm{Cu}$ (II) or $\mathrm{Co}$ (III) complexes of the Cyc-containing inhibitors act as CPA-cleaving catalysts. the $\mathrm{Cu}$ (II) or $\mathrm{Co}$ (III) complex of $\mathrm{I}_{\mathrm{proc}}{ }^{2}$ or $\mathrm{I}_{\mathrm{Fhe}}{ }^{2}$ was mixed with CPA under the conditions of $E_{0}>I_{0}$. The activity of CPA was inhibited to similar extents by the metal-bound or metal-free Cyc-containing inhibitors. indicating that the metal complexes are effectively bound by CPA. In order to obtain positive evidence for cleavage of CPA by the $\mathrm{Cu}(\mathrm{II}) \mathrm{Cyc}$ - or Co(III)Cyc-containing inhibitors. two kinds of experiments were performed. First. whether the degree of inlibition of CPA activity by the added inhibitor exceeds the amounts of the inhibitor was checked to examine the catalytic turnover of the CPA cleavage. Second formation of new protein fragments upon incubation of CPA with the $\mathrm{Cu}(\mathrm{II}) \mathrm{Cyc}$ or 
Table 1. Values of $K_{\mathrm{i}}$ for various CPA inhibitors ${ }^{a, b}$

\begin{tabular}{|c|c|c|c|}
\hline Inluibitor & $K_{1}(\mathrm{pM})$ & Inluibitor & $K_{1}(\mathrm{pM})$ \\
\hline $\mathrm{I}^{\mathrm{l}}$ & No inhibition & $\mathrm{I}^{2}$ & $900 \pm 90$ \\
\hline $\mathrm{I}_{\mathrm{Gjy} \mathrm{y}}{ }^{\mathrm{j}}$ & $4200 \pm 1000$ & $\mathrm{Loly}^{2}$ & $82 \pm 5$ \\
\hline $\mathrm{I}_{(\mathrm{g}) \mathrm{y}(\mathrm{j}) \mathrm{y}^{\mathrm{l}}}$ & $3200 \pm 900$ & $\mathrm{IOJyOHy}_{y}^{2}$ & $26 \pm 3$ \\
\hline $\mathrm{I}_{\mathrm{A} \mathrm{Ja}^{3}}{ }^{\mathrm{s}}$ & $90 \pm 22$ & $\mathrm{I}_{\mathrm{AJa}^{2}}{ }^{2}$ & $8.4 \pm 0.2$ \\
\hline $\mathrm{I}_{\beta-A<\left.\right|^{1}}$ & $900 \pm 90$ & $I_{\beta-A a^{2}}{ }^{2}$ & $180 \pm 30$ \\
\hline$I_{l l e}{ }^{\prime}$ & $260 \pm 80$ & $\mathrm{I}_{[] \mathrm{e}^{2}}$ & $15 \pm 2$ \\
\hline$I_{P S}{ }^{1}$ & $77 \pm 28$ & $\mathrm{I}_{\mathrm{PN}^{2}}{ }^{2}$ & $4.8 \pm 0.4$ \\
\hline $\mathrm{I}_{\mathrm{Phe}}{ }^{1}$ & $2100 \pm 400$ & $\mathrm{IPhe}^{2}$ & $59 \pm 27$ \\
\hline $\mathrm{A}_{1}$ & 0.02 & $\mathrm{~A}_{2}$ & l \\
\hline $\mathrm{A}_{3}$ & 3 & $A_{4}$ & 4 \\
\hline As & 20 & $A_{0}$ & 710 \\
\hline
\end{tabular}

$" 25{ }^{\circ} \mathrm{C} . \mathrm{pH} 7.5,0.5 \mathrm{M} \mathrm{NaCl} .0 .05 \mathrm{M}$ Tris or Hepes. ${ }^{~}$ Data for $\mathrm{A}_{1}-\mathrm{A}_{6}$ were taken from the literature. ${ }^{\text {t.1. }}$

Co(III)Cyc derivatives was examined by MALDI-TOF MS. Several experiments were performed under various conditions. but no positive evidence was obtained for the cleavage of CPA by the inhibitors.

The $\mathrm{Cu}$ (II) or $\mathrm{Co}$ (III) complex of $\mathrm{I}_{\mathrm{pro}}{ }^{2}$ or $\mathrm{I}_{\mathrm{Phe}}{ }^{2}$ contains an effective binding site for CPA as well as the peptide-cleaving catalytic center. Although the $\mathrm{Cu}(\mathrm{II})$ or $\mathrm{Co}$ (III) complex of $\mathrm{I}_{\mathrm{pro}}{ }^{2}$ or $\mathrm{I}_{\mathrm{Phc}}{ }^{2}$ occupies the active site of CPA. it failed to cleave the peptide back-bone of CPA. It appears that the $\mathrm{Cu}(\mathrm{II}) \mathrm{Cyc}$ or Co(III)Cyc moiety was not positioned in a productive location close to a peptide group in the complex formed with CPA. Results of the present study suggest that the structure of the linker (Scheme 1) connecting the catalytic group and the binding site must be optinized in order to design effective target-selective peptide-cleaving catalysts exploiting known ligands of the target protein.

\section{Experimental Section}

CICPL was prepared as reported in the literature. ${ }^{7,8}$ For synthesis of Cyc-containing inhibitors. 1 and 7 were prepared according to the reported methods ${ }^{3.9}$ MALDI-TOF MS data for the inhibitors listed in Figure 1 are: $m z 486.68$ $(\mathrm{M}+\mathrm{H})^{+}$for $\mathrm{I}^{\mathrm{l}} / \mathrm{I}^{2}\left(\mathrm{C}_{21} \mathrm{H}_{36} \mathrm{~N}_{3} \mathrm{O}_{6} \mathrm{P}\right.$ calcd. 486.52$) ; m z 543.62$

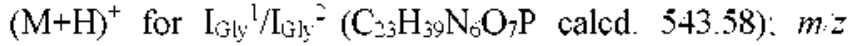

$600.70(\mathrm{M}+\mathrm{H})^{+}$for $\mathrm{I}_{\mathrm{GlYGly}}{ }^{1} / \mathrm{I}_{\mathrm{GlYGly}}{ }^{2}\left(\mathrm{C}_{2} \leq \mathrm{H}_{42} \mathrm{~N}_{7} \mathrm{O}_{8} \mathrm{P}\right.$ calcd. 600.63): $m z 557.51(\mathrm{M}+\mathrm{H})^{-}$for $\mathrm{I}_{\mathrm{Ala}^{2}}{ }^{1} / \mathrm{A}_{\mathrm{Aa}}{ }^{2}\left(\mathrm{C}_{44} \mathrm{H}_{41} \mathrm{~N}_{6} \mathrm{O}_{7} \mathrm{P}\right.$

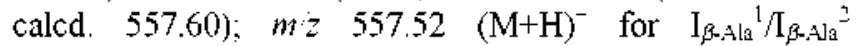
$\left(\mathrm{C}_{24} \mathrm{H}_{41} \mathrm{~N}_{6} \mathrm{O}_{7} \mathrm{P}\right.$ calcd. 557.60): $m z 599.61(\mathrm{M}+\mathrm{H})^{+}$for $\mathrm{I}_{\mathrm{Ill}}{ }^{1} /$ $\mathrm{I}_{\mathrm{Ile}}{ }^{2}\left(\mathrm{C}_{77} \mathrm{H}_{47} \mathrm{~N}_{6} \mathrm{O}_{7} \mathrm{P}\right.$ calcd. 599.69): $m z 583.69(\mathrm{M}+\mathrm{H})^{+}$for $\mathrm{I}_{\mathrm{Pro}}{ }^{1} / \mathrm{C}_{\mathrm{Prc}}{ }^{2}\left(\mathrm{C}_{76} \mathrm{H}_{43} \mathrm{~N}_{6} \mathrm{O}_{7} \mathrm{P}\right.$ calcd. 583.64); $m z 633.63(\mathrm{M}+\mathrm{H})^{-}$ for $\mathrm{I}_{\mathrm{hhe}}{ }^{1} / \mathrm{IPhe}^{2}\left(\mathrm{C}_{33 \mathrm{l}} \mathrm{H}_{45} \mathrm{~N}_{6} \mathrm{O}_{7} \mathrm{P}\right.$ calcd. 633.70). For separation of the diastereomeric mixtures of the Cyc-containing inhibitors. a 100 series HPLC system (Agilent Technology) was used with the variable-wavelength UV detector set at $260 \mathrm{~nm}$. A $250 \times 4.6 \mathrm{~mm}$ I.D. reversed-phase Hypersil BDS $\mathrm{C}_{18}$ column (Hypersil) was used. A gradient separation was performed with solvents $\mathrm{A}$ and $\mathrm{B}$ (A. $0.05 \mathrm{~N}$ triethylammonium bicarbonate in $\mathrm{H}_{2} \mathrm{O}$ pH $7.4 ; \mathrm{B}, 0.05 \mathrm{~N}$ triethylanmonium bicarbonate in $47 \%$ aqueous methanol, pH 7.4): $0-10$ min with $10 \% \mathrm{~B} ; 10-30 \mathrm{~min}$ with $10 \%$ to $100 \% \mathrm{~B}, 30-35 \mathrm{~min}$ with $100 \%$ to $10 \% \mathrm{~B}$. The $\mathrm{Cu}$ (II) complexes of the $\mathrm{Cyc}$-containing inhibitors were generated by adding 0.8 equiv of $\mathrm{CuCl}_{2}$ to the solution of the respective inhibitors. The Co(III) complexes of the Cyc-containing inhibitors were obtained as described previously. ${ }^{3} \mathrm{CPA}$ (Cox form) was purchased from Sigma and was used after washing the enzyme crystals with water at $4{ }^{\circ} \mathrm{C}$. To prevent deactivation of $\mathrm{CPA}$ at $<1 \mu \mathrm{M}$, bovine serum albumin (0.1 $\mathrm{mg} / \mathrm{mL})$ and $\mathrm{ZnCl}_{2}(1, \mu \mathrm{M})$ was added. ${ }^{4.5}$

Acknowledgment. This work was supported by Korea Research Foundation Grant (KRF 2001-015-DS0029).

\section{References}

1. Jeon. J. W.; Son. S. J.; Yoo. C. E.; Hong, I. S.; Song, J. B.: Suh, J. Org. Lett. 2002. 4. 4155.

2. Suh. J. Acc. Chem. Res. 2003. 36.562 .

3. Jeonl. I. W.: Son1. S. T.: Yoo. C. E.: Hong. I. S.: Sul. J. Bioorg. Med. Chem 2003. 11. 2901.

4. Hanson. J. E.; Kaplan, A. P.: Bartlett, P. A. Biochenistry 1989, 28. 6294.

5. Kaplan. A. P. Bartlett, P. A. Biochemisty 1991. 30,8165

6. Kim. J.: Lipscomb. W. N. Biochemistry 1991. 30.8171 .

7. Suh. J.: Kaiser. E. T. J. Am. Chent. Soc. 1976. 98. 1940.

8. Sulh. T.: Cho. W: Chung. S. J. Ant Chem. Soc. 1985. 107. 4530 .

9. Odeksyszyn. J.: Matalerz. P. Synthesis 1979.985. 